SOME RADIOISOTOPE ASSAY METHODS

\author{
S. A. Reynolds
}

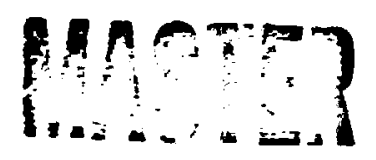




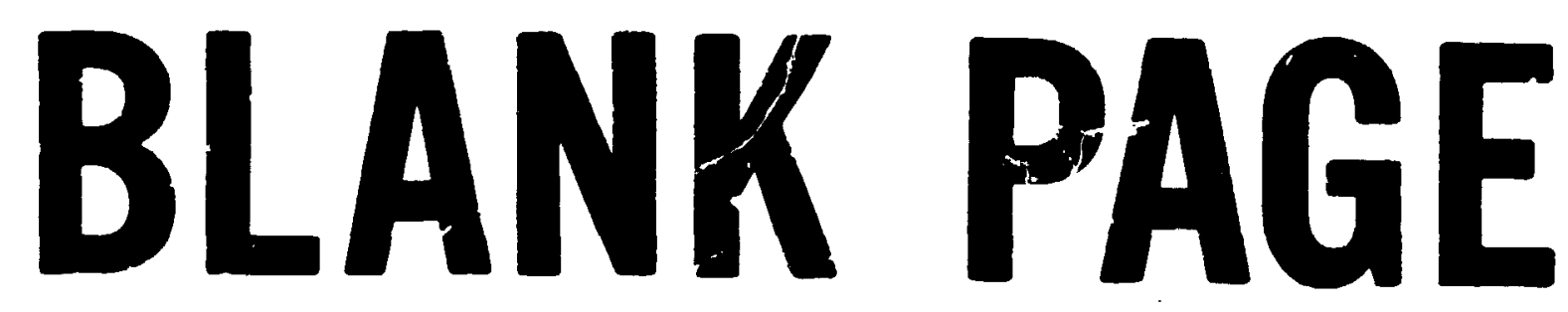


Printed in the United States of Amenca. Avalable irom Norional Technical Information Service

U.S. Department of Commerce

5285 Pon Royal Road. Springfield. Virgina 22151

Price Printed Copy 54.00: Microfiche se.9s

This report wos preperer; as on acexunt of mork spensored oy the linited Seates Government. Neitter the Unitat Staves nor the United Steses Atomic Enerey Commission. nor any of their employees. nor any of their contractors. subcor:trac:ors, or their employes, mokes any marranty, express or intolied, or assumes any leger labblity or responsibality for the accuracy. completeness of usefulness of any information. apperatus. product or proces eisilosed, or represents that its use rould not infringe privatefy ommed rights. 
URNL $-4^{-} 88$

UC-23 - Radioisotope and

Radiation Applications

Contract Ho. N-7405-eng-26

ISOTOPES DCVELOPAAT CEITER

OOME RADIOISOTOPE ASSAY METHODS

S. A. Reymolds

Isotopes Division and Analytical Chenistry Divisinz

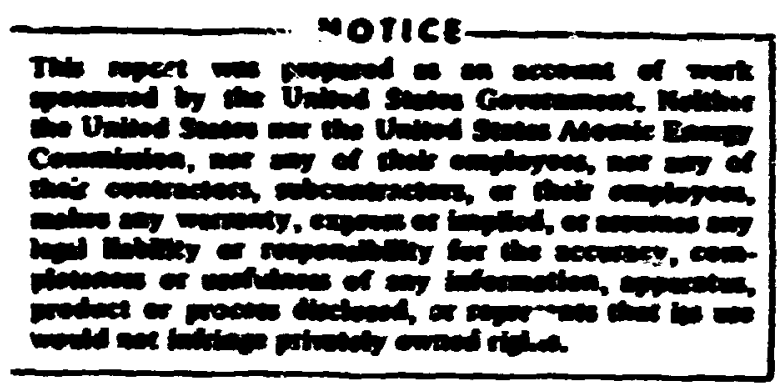

MARCH 1973

OAK RIDGE NATIONAL LAEDRATORY

Oak Ridge, Tennessee $\$ 7830$ operated by UNION CARBIDE CORPORATION for the

U.S. ATOMIC ERERGY COMISSION 
SULARY . . . . . . . . . . . . . ....... 1

InIRODUCtIOA ....................... 1

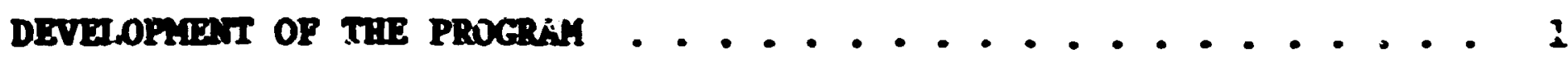

STAMARdizatica ...................... 2

Direct Eechiques ..................... 3

C soide Standards ..................... 3

lleed for Muclear Data ................. 6

APPLIED MRASURDGaTS ...................... 6

Specifis Instrunents ................. 6

Qualiry control ................... 8

persomnel ...................... 8

ASSAY OF SELECTED RADIONDCLIDES . . . . . . . . . . . . 10

Carbon-14 ...................... 10

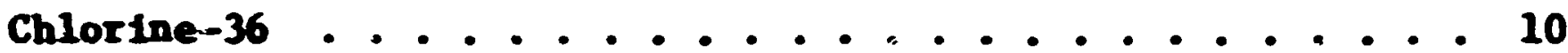

$\operatorname{Ircn}-55$. . . . . . . . . . . . . . . 10

Iron-59 ......................... 11

Micke1-63 ....................... 11

Krypton-85 ....................... 11

Iodine-131 ....................... 11

Prosethiua-147 .................... 11

SUGGESTIOAS FOR RADIOAUCLIDE MRASURERTNS . . . . . . . . . 12

Requirements for Standards . . . . . . . . . . . . 12

Personnel ...................... 13

Equipment ........................ 15

Some Physical Sources of B.ror . . . . . . . . . . . 15

Chentcal Considerations ................ 15

Quality Control ..................... 16

ACTMONLEGERTS . . . . . . . . . . . . . . . . 17

BETERTICES . . . . . . . . . . . . . . . . 18 
SOME RADIOISOTOPE ASSAY METHODS

\author{
S. A. Reunolds
}

\begin{abstract}
SUMARY
A Izview is preinted of over a quarter-century of work in ca!.sbrations for ORIL radiolsotope products. Internal standardizations are surveyec, and details are given of measurements of merials produced by standardizing laboratories, particularly the Rational Bureau of Standards (MBS). The need for rellable nuclear data is stressed. Specific information, historical as well as current, is included on eight representative products. General suggestions are made for the benefit of others who are required to measure radionuclides. Tiens included are standards, personnel, equipment, and quality conr.rol.
\end{abstract}

\title{
INTRCOUCTION
}

For nearly tirree decades radionuclides have been produced at Oak Ridge Dat fonal Laboratory (ORI). This report surveys their cellibration and measurement. Reviews were published about one ${ }^{1}$ and $t w 0^{2}$ decades after initiation of the progran, and litile of that saterial is repeated. The work described here han beer part of a cooperative prograa ${ }^{3}, 4$ of the Isotopes and Analytica?. Cheatstry Divisions; woch of the experimentation has been performed by messerz of the latter division. The facilities and expertise have been applied in support of activities of a nuber or other divisions, 5 surh as Healtr Physics, ${ }^{6}$ Reactor Chenistry, and Operations; but the present discussion is linited to Isotopes Division work.

Discussion is further linted to laboratory-level calibrations expressed in disintegration rate or microcurie units. Large-surce methods such as calorinetry and dosinetry (expressed in rads) have been covered elsewhere. ${ }^{7-10}$ Purity of miterials noeds to be considered only as it affect's their masurewent.

\section{DEVELOPMENT OF THE PROGRM}

A forval quality-control progran on radiolsotopes has never been set up, but there have been conscientious effort and excellent cooperation anons routine and specialized analytical personnel and production workers. Although occasional errors - perhaps in dilution or calculation - have been made, few legttinate challenges of local callbratioas have arisen. A great anforlty of usere' complaints about ascays have besa show to be due to lack of bastc nuclest or radiochentcal information or their poor 
standardization. The local progran has required measureient of over 175 nuclides, comparable to numbers needed at other large laboratories, for exanole, about 170 at the British Radiochenical Centre (RCC) ${ }^{11}$ and 125 at Pacific Northiest Laboratories. 12

Because of the world-wide use of radioisotopes, the progran has always been outwardly directed, involving cooperation with the Hational Bureau of Standards (MBS; , International Atonic Energy Agency (IAEA), Public Health Service (PAS), Anericail Society for Testirg and Materials (ASTI), Hational Research Council (ARC) (particularly its Subinattee on the Hse of Radioactivity Szandards ${ }^{13}$ ), and otier organizations. Sucin cooperation included supplyirg cF matertals, assisting in preparation of documents (such as a netrol-83 hardbook ${ }^{14}$ and ASTM methods ${ }^{15}$ ), participating in conferences, 16-19 and taking part in intercoparisons. $1,16,1 \mathrm{e}, 20,21$ The author conducted a survey ${ }^{20}$ for an lRC panel on siandards; this survey served as the principal fartual basis for the panel's report. 22

An informal progran of training in measurenent techniques vas carried on, largely in the years 1950-1965. Participants included personnel of the Mational Reactor Testing Station, the Savannah River Laboratory, PHS, etc., and scientists from Africa, Argentina, Greece, India, Thailand, and elsewhere. The author taught an informal "Analvtical Radiochenistry Survey Course" 16 times during that period.

OWI has never claimed to issue stantards' or to calibrate routine shipwents, thus negating its designztion"l as one of the "standardizing laboracorfes." Horever a nuber of requests for standards was received, and some users have enployed shipments for calibration. On a far occasions, "analyzed saples" were furnisbed, e.g., to a Hew Zealand laboratory in 1954, to ABC Comissioner Libby in 1956,23 and to PHS in 19t. Methods for 60 radionuclides were tabulated in a memo in 1956 and were quoted (with BS methods for 19 nucliles) in a reference book. ${ }^{4}$ later information was given in a journal article, 25 the ORWL Master Analytical Manual, 26 and the Isctupe Iser's Guide. 27

\section{STAMDARDIZATION}

Because of some discrepencies in their usage, the term primary and absolute are avolded. Instead, direct is applied to techniques such as $4 \pi$, ccincidence counting, or definet geometry (for alpha), which yield disintegration rates directly. Derfied calfbrations are based, e.g-, on energyefficiency curves for ionization chabers or spectroneters. A standard, or stendard reference enterial (SMH), is furnished by a specialized laboratory such as BBS. A substitute standard 1 s a nuclide of properties, t.8., beta caergy, sindlar to the desired nuclide but having characteristica, such as a longer half-1ife, that mike its use mere practical. The oubject of atandsrdization has been covered thoroughly 1: the 11terature, 2,14,16-10,28-31 and no atteapt 111 be wide to seview 1 bere. Each nuclide mut be considered Individually, bence the detalled sections later in this report. 


\section{Direct Techniques}

Callbrations at ORN were essentielly "stare-of-the-art", involving such now-faniliar methods as $4 \pi$ beta counting, coincidence countjing (including $4 \pi$ beta-gamea $\left.32,3^{3}\right)$, and defined geonetry. In addition, several direct methods of less wide appitcation were devised, including $x-g^{2}$ ma $^{3+}$ and alpha-gana 32 colncidence and "absolute" liquid scintillation. ${ }^{35}$

\section{Outside Standards}

Of necessity, calibrations at ORIL antedated work by NBS or any international organization (except on ${ }^{226} \mathrm{Ra}$ ). Further, anclytical requirements had short "lead times," as new radioisotope products were developed very rapidly, or especially wen unexpected impurities required imediate assay. No outside laboratory could be expected to keep pace. The first NBS SBM's in 1948-1950 were used for intercomparisons, and problems were encountered. ${ }^{2}, 16$ Soon, howtiei, the progran becane quite active, 21 and the stardards which were issued were very reliable. A policy of not competing with comercial suppliers resulted in transfer of resporsibility for certain auclides to Huclear-Chic.1go Corporation in 1957 and generally has kept the IBS progran smill. Sore solution and point-source standards are issued, ${ }^{36}$ and routine calsuraticns are offered for certain nuclides. ${ }^{37}$ In addition, a nonroutine calibration service is said to be available, but shortage of personnel and funds and necessity of advance programing of work have resulted in the inability to fulfill most request 3.22

The value of intercomparisons with rellable laboratories was recognized early, ei pecially by the author, for the obvious purpose of confining local calibrations, as vell as for evaluating the SRY's offered and anticipating questions of lsotope users who might calfbrate by means of those SBM's. Traceability to IBS was especially desirable, though not dictated by regulations or by wide explovent of MBS SRY's by uzers, ${ }^{22}$ domestic or forelgn. The practice by Nuclear-cicago of hiving aster solutions measurad by laBS ade it possibie to continue to relate some local and ABS calibrations indirectly ${ }^{38}$ until 1 . B. The anllness of the MBS progran resulted in invasion of the domestic arket in the $1960^{\prime} \mathrm{s}$, especially by RCC and IAFA, and quite a few of those froducts were neasured locally. Typical early results have been aumarized, 1,2 and recent ones are given in Table 1. It should be noted that agreenent with NBC is comarabie :0 that with other standardizing laboratories. (Mickel-63 is discussed in a later section.)

Radiolsotope materials were gradusily withdrawn from production at $0 \mathrm{Br}$, and the pe sonnel who had performed direct calibrations were transferted to other prograns. It, therefore, berane neceseary to depead wore on outside standards. In addition, the RRC standards panel strongly reconmended 22 establishment of traceability to MBS, thus strengthening the trend. 


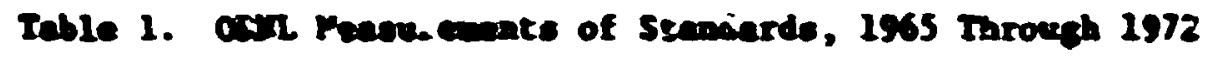

\begin{tabular}{|c|c|c|c|c|}
\hline rellde & Dalf-Life & $\begin{array}{l}\text { Oridedx of } \\
\text { stapdard }\end{array}$ & $\begin{array}{l}\text { Year of oun } \\
\text { teapurement }\end{array}$ & $\begin{array}{c}\text { Dif ferrace } \\
\text { (x) } \\
\end{array}$ \\
\hline Byarogen-3 & $12.3 \mathrm{~J}$ & as & 1971 & 0.4 \\
\hline Carboen-16 & $5730 \mathrm{y}$ & $\frac{\mathrm{ms}}{\mathrm{ms}}$ & $\begin{array}{l}1867 \\
1971\end{array}$ & $\begin{array}{l}1.0 \\
0.0\end{array}$ \\
\hline Sod:Le-22 & $2.60 \mathrm{y}$ & $\begin{array}{l}\text { IAP } \\
\text { IASA } \\
\text { IAR }\end{array}$ & $\begin{array}{l}1965 \\
1 \% 67 \\
1968\end{array}$ & $\begin{array}{l}0.5 \\
1.3 \\
1.0\end{array}$ \\
\hline Froephorwe-32 & $16.3 d$ & $\begin{array}{l}\text { Ws } \\
\text { ecc }\end{array}$ & $\begin{array}{l}1972 \\
1972\end{array}$ & $\begin{array}{l}0.1 \\
3.8\end{array}$ \\
\hline Salfur-35 & $38 d$ & $\begin{array}{l}\text { Iard } \\
\text { Iald } \\
\operatorname{coc} \\
1 \mathrm{~s} \\
\mathrm{csi} \\
\mathrm{ncc}\end{array}$ & $\begin{array}{l}1967 \\
1968 \\
1970 \\
1971 \\
1971 \\
1971\end{array}$ & $\begin{array}{l}3.0 \\
0.6 \\
0.8 \\
2.8 \\
2.5 \\
2.8\end{array}$ \\
\hline C.1orise-36 & $0.30 \mathrm{ks}$ & $\begin{array}{l}\text { Ms } \\
\text { ms } \\
\text { ms }\end{array}$ & $\begin{array}{l}1965 \\
1969 \\
1970\end{array}$ & $\begin{array}{l}2.7 \\
4.8 \\
0.8\end{array}$ \\
\hline$\Delta r y=37$ & i5 d & ms & 1972 & 3.5 \\
\hline Calcter-45 & $1.64 d$ & $\begin{array}{l}n-c \\
\operatorname{rec} \\
\operatorname{mcc}\end{array}$ & $\begin{array}{l}1967 \\
1969 \\
1972\end{array}$ & $\begin{array}{l}5.9 \\
6.4 \\
0.0\end{array}$ \\
\hline reacenece-54 & $313 d$ & $\begin{array}{l}\text { IAEA } \\
\text { ueA } \\
\text { weA } \\
\text { wes }\end{array}$ & $\begin{array}{l}1965 \\
1967 \\
1967 \\
1968\end{array}$ & $\begin{array}{l}0.2 \\
1.1 \\
1.4 \\
1.3\end{array}$ \\
\hline Iroe-55 & $2.7 \mathrm{~J}$ & $\frac{\text { MPS }}{\text { IS }}$ & $\begin{array}{l}1969 \\
1959\end{array}$ & $\begin{array}{l}3.6^{c} \\
2.6^{c}\end{array}$ \\
\hline Irom-59 & $44.6 d$ & us & 1970 & 0.4 \\
\hline Cobalt-57 & $271 d$ & 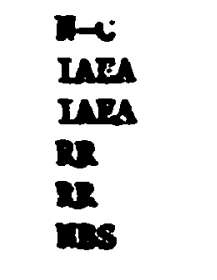 & $\begin{array}{l}1965 \\
1967 \\
1968 \\
1968 \\
1969 \\
1972\end{array}$ & $\begin{array}{l}1.2 \\
1.3 \\
0.1 \\
1.4 \\
1.7 \\
1.1\end{array}$ \\
\hline Cobant-60 & $5.27 \mathrm{~J}$ & 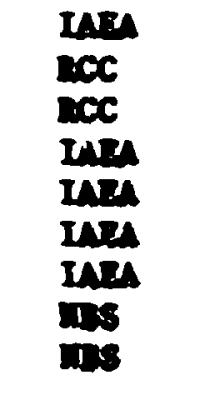 & $\begin{array}{l}1965 \\
1965 \\
1966 \\
1967 \\
1968 \\
1969 \\
1970 \\
1971 \\
1972\end{array}$ & $\begin{array}{l}0.4 \\
0.3 \\
0.2 \\
0.3 \\
1.8 \\
0.7 \\
0.9 \\
1.3 \\
2.8\end{array}$ \\
\hline nicker -63 & $100 \mathrm{~F}$ & $\begin{array}{l}\text { noc } \\
\text { ms }\end{array}$ & $\begin{array}{l}1967 \\
1969\end{array}$ & $\begin{array}{r}4.6 \\
17.3\end{array}$ \\
\hline call10-67 & $78 \mathrm{~b}$ & $2 x c$ & 1972 & 0.8 \\
\hline saloat-75 & 120 & $\mathbf{m}$ & $\begin{array}{l}1965 \\
1969\end{array}$ & $\begin{array}{l}2.6 \\
3.6\end{array}$ \\
\hline inptean-3s & $10.7 \mathrm{y}$ & Ins & 1970 & 1.7 \\
\hline absde-es & $18.7 d$ & $\operatorname{mcc}$ & 1966 & 0.2 \\
\hline Itirten-68 & 107 & $\begin{array}{l}\text { Wh } \\
\text { un }\end{array}$ & $\begin{array}{l}1967 \\
1969\end{array}$ & $\begin{array}{l}0.4 \\
2.2\end{array}$ \\
\hline seronten-so & $20.5 \mathrm{y}$ & $\begin{array}{l}\text { ines } \\
\text { wen }\end{array}$ & $\begin{array}{l}1966 \\
1960\end{array}$ & $\begin{array}{l}1.0 \\
1.0\end{array}$ \\
\hline rulyedeaness & $66.2 \mathrm{~h}$ & $\mathbf{m e c}$ & $\begin{array}{l}1967 \\
1966\end{array}$ & $\begin{array}{l}2.7 \\
0.6\end{array}$ \\
\hline
\end{tabular}


Table 1. continued

\begin{tabular}{|c|c|c|c|c|}
\hline Mucllde & Hali-L1fe & $\begin{array}{l}\text { Origin of } \\
\text { Standard }\end{array}$ & $\begin{array}{l}\text { Year of ORKL } \\
\text { Hengurement }\end{array}$ & $\begin{array}{c}\text { Difference } \\
(\mathrm{z})\end{array}$ \\
\hline Technet In-99e & $6.02 \mathrm{~h}$ & $\mathbf{R R}$ & 1968 & 0.6 \\
\hline Rucbenium-1C3 & $39.5 d$ & $\mathbf{B C C}$ & 1966 & 2.3 \\
\hline Rutbealum-106 & $1.01 \mathrm{y}$ & $\begin{array}{l}\text { RCC } \\
\text { RCC }\end{array}$ & $\begin{array}{l}1966 \\
1968\end{array}$ & $\begin{array}{l}0.3 \\
0.4\end{array}$ \\
\hline Codaiv-109 & $462 d$ & $\begin{array}{l}\text { MBS } \\
\text { RCC }\end{array}$ & $\begin{array}{l}1971 \\
1972\end{array}$ & $\begin{array}{l}2.0 \\
0.0\end{array}$ \\
\hline silver-110n & $250 d$ & $\mathrm{RCC}$ & 1970 & 0.6 \\
\hline Indive-114a & $49.5 d$ & Rcc & 1967 & 0.2 \\
\hline Iodine-125 & $60 d$ & $\begin{array}{l}\text { RR } \\
\text { RBS }\end{array}$ & $\begin{array}{l}1969 \\
1972\end{array}$ & $\begin{array}{l}1.3 \\
i .2\end{array}$ \\
\hline Iodine-131 & $8.05 d$ & $\begin{array}{l}\text { N-C } \\
\text { MES }\end{array}$ & $\begin{array}{l}1967 \\
1972\end{array}$ & $\begin{array}{l}1.8 \\
0.7\end{array}$ \\
\hline Ienon-133 & $5.29 d$ & MS & 1972 & $a \gamma^{d, e}$ \\
\hline Cestu-131 & $9.7 \mathrm{C}$ & $\operatorname{scc}$ & 1967 & $10.6^{d}$ \\
\hline Cesiu-134 & $2.06 \mathrm{y}$ & $\operatorname{scc}$ & 1969 & 3.7 \\
\hline Cesiun-137 & $30 \mathrm{y}$ & $\begin{array}{l}\text { LAEA } \\
\text { IAEA } \\
\text { IAEA } \\
\text { LEA } \\
\text { IAEA } \\
\text { IAEA } \\
\text { IDS }\end{array}$ & $\begin{array}{l}1965 \\
1967 \\
1967 \\
1968 \\
1969 \\
1970 \\
1972\end{array}$ & $\begin{array}{l}2.5 \\
1.0 \\
0.2 \\
2.1 \\
0.3 \\
1.3 \\
2.2\end{array}$ \\
\hline Barlum-1 33 & $10.5 \mathrm{y}$ & RCC & 1966 & 0.0 \\
\hline Cerius-144 & $284 d$ & MBS & 1966 & 3.2 \\
\hline Heodyniue-147 & $11.0 \mathrm{~d}$ & ReC & 1968 & 1.7 \\
\hline Pronethium-147 & $2.62 \mathrm{y}$ & $\begin{array}{l}\text { RBS } \\
\text { RR } \\
\text { RR } \\
\text { RCC }\end{array}$ & $\begin{array}{l}1966 \\
1966 \\
1966 \\
1966\end{array}$ & $\begin{array}{l}1.4 \\
1.6 \\
0.6 \\
3 . ?\end{array}$ \\
\hline Thul Iu--170 & $128 d$ & RCC & 1966 & 1.8 \\
\hline Mercury-197 & $64 \mathrm{~h}$ & $\begin{array}{l}\mathbf{R} \\
\mathbf{R R}\end{array}$ & $\begin{array}{l}1.966 \\
1967\end{array}$ & $\begin{array}{l}0.0 \\
2.9\end{array}$ \\
\hline Mercury-203 & $46.7 \mathrm{~d}$ & $\begin{array}{l}\text { BCC } \\
\text { IAEA } \\
\text { IAEA }\end{array}$ & $\begin{array}{l}1966 \\
1967 \\
1968\end{array}$ & $\begin{array}{r}10.3 \\
3.0 \\
5.2\end{array}$ \\
\hline \multirow[t]{2}{*}{ Anericium-241 } & $433 y$ & $\begin{array}{l}\text { IAES } \\
\text { IAEA }\end{array}$ & $\begin{array}{l}1967 \\
1968\end{array}$ & $\begin{array}{l}5.7^{f} \\
1.9^{f}\end{array}$ \\
\hline & Ave & ge difference: & $\begin{array}{l}\text { Overal1 } 8 \\
\text { MBS }\end{array}$ & $\begin{array}{l}1.9 \\
2.4^{h}\end{array}$ \\
\hline
\end{tabular}

\footnotetext{
Deterndied or adopted by oral.

${ }^{\mathrm{b}} \mathrm{CE}$ - Prench condesariat a l'Energie Atonique

LARA - Intermational Atonic Bnergy Agency

H-C - Huclear-Chicago (etocks checked by mBS)

XBS = U.S. Mational Bureau of Standards

RCC = British Rediochenteal Centre

RR = Intercompertion; difference is ietween ORI and "beet" or average value.

CDifferences in opposite senses.

dSubpect, refected fron average.

EIndirect comparinon; mak eaple.

f By gana; elpha preforable.

841 nuclides, 92 eamp'es.

h22 acples; $1.7 \%$ wiliout nickel -63 .
} 
Need for Nuclear Data

Proper use of SRH's - as well as radicisotope projucts themselves - requires knowledge of half-1ives and deray schemes. ${ }^{2}$ Impcrtant compilations in this field have been dore oy groups at Berkeley ${ }^{39}$ and lak Ridge.40,41 The National Science Doundation has supported an active program, based on recommendations ${ }^{42}$ by RRC. Compilations quickiy beconie obsolete, 42 and most do not contain needed inforwation such as gama percentiges (photons per 100 disintegrations). Therefore, radiolsotope-analy.3is personnel have been forced to ane selectlons, 2,27 for example, a table 4: $^{2}$ and the author's abapter 44 in a handboos. In addition, many half-lives ${ }^{45}$ and seme decayecheme parameters ${ }^{2}$ bave been deternined experimentally. A study was recently ade of the percentage of $88-\mathrm{keV}$ gamea radiation $\mathrm{in} 109 \mathrm{Cd}$, a userul standard also enitting $22-\mathrm{keV} x$ rays. The jalue was $3.8 \pm 0.1 \%$, in agreewent with an estinate by D. J. Horen of the ORNL Nuclear Data Group and .un unpublished resuli by Prench Investigstors.

\section{AFPLIED IIEASUPEMENTS}

Ratabilshment of the "efficiency factor" of an instrument for measurement of a particular nuclide is a eimle metter when a SRM of that nuclide at es appropriate level of activity is available. Most nuclides a:e shortIlved so thet a normalizing source of simflar radiation properties but of extreneiy long or well known half-life 18 measured at the same time as. the SRI, and subsequent zeasurements of the nuclide are adjusted by means of the ac rallizing source. Radium-226, ${ }^{137} \mathrm{Cs}, 133 \mathrm{Ba}$, and natural uranium have been used as gama reference sources. Cobalt $-60,1{ }^{4} \mathrm{C}$, uranium, etc., huve been used for beta normal1zazion, and $23{ }^{3} \mathrm{U}$ and $23{ }^{9} \mathrm{Pu}$ for alpha. SRM's and local direct cal:urations have not been available for many of the radiolsotopes produced at ORIL. Substitute standards and calibration curves have therefore been widely used. Most. difficulty has heen experienced witt. low-energy beta or $x$-ray emitters. In some cases, standardizable gana nuclides entting ginilar beta or $x$ radiation were used to callbrate instrument.8, e.8.. ${ }^{95} \mathrm{ht}$ ior ${ }^{35} \mathrm{~S}$ and ${ }^{60} \mathrm{Co}$ for ${ }^{+5} \mathrm{Ca}$, foreshadowin? she "efficiency tracing" cechntque. 31

\section{Specific Instruments}

A table has been given ${ }^{2}$ showing types of instruments and times of adoption for radiolsotope wrk and descriptions and principles of operation have been published. $14,26,31,46$ A.pha efficiency of a $2 r$ proportional counter for a flat thin source $i s$ essentially independent of energy and 18 about 517 for nickel or stainlese steel backing and 527 for platinum becking. Liquid scintillation counting for weak beta emitters requires standards of the particular asclides, and dffficulties with sorption and other effects sometimes arise, requiring, for exsmple, addition of small quantities of carriers. For other beta emitters, $2 \pi$ or end-window counters are used; the latter require extrapolative correction, 47,48 using a standard of comparable energy, for the windor and intervening air. $x$ rays are counted by means of an end-kindow proportional 34,49 or 
semiconductor ${ }^{49}$ detector. Whenever feasible, a nuclide is measured by its gamma radiation. Standard efficiency-versus-energy curves are available for $\mathrm{NaI}(\mathrm{TI})$ detectors, ${ }^{48-50}$ and a curve can be prepared For a given semiconductor deiector. It should be noted that for spectrometers the accuracy of the compited efficiency for a particular nuclide is dependent on the reliability of decay.-scheme information to a greater degree than for mosc other instruments.

Special attention is given here to the $4 \pi$ gamma lonization chamber (GIC), because of its precision (about $0.2 \%)$, useful range (over $10^{+}$), relative insensitivity to sampl'a vilume, and wide use, particularly in midical ("dose calibrators") and general-assay work. The ORN, model $5 i-: 3$ is filled with argon under pressure and is similar to one at $\mathrm{NBS}^{20}$ and some of the "NPL chambers." 54 The local GIC's are caltbrated with ${ }^{60}$ Co solu$t$ Ion samples from a stock whose disintegration rate has been determined by coincidence counting. Efficiencies for other nuclides ${ }^{53}$ relative to ${ }^{60} \mathrm{Co}$ are determined by measurement of knoks sources of those nuclides or are cálculated from information on their decay schemes coupled with an experimental efficiency plot like Fig. 1. It is apparent that the presence of a high-energy impurity would have an effect proportionately larger than its relative concentration. Response varies with temperizure, and, in addition, a long-term drift may take place so that it ir necessary to adjust readings by use of normalizing sources of ${ }^{226} \mathrm{Ra}$. Principles ${ }^{52}$ of calibration and use have remained the same since early in the radioisotope program. 51

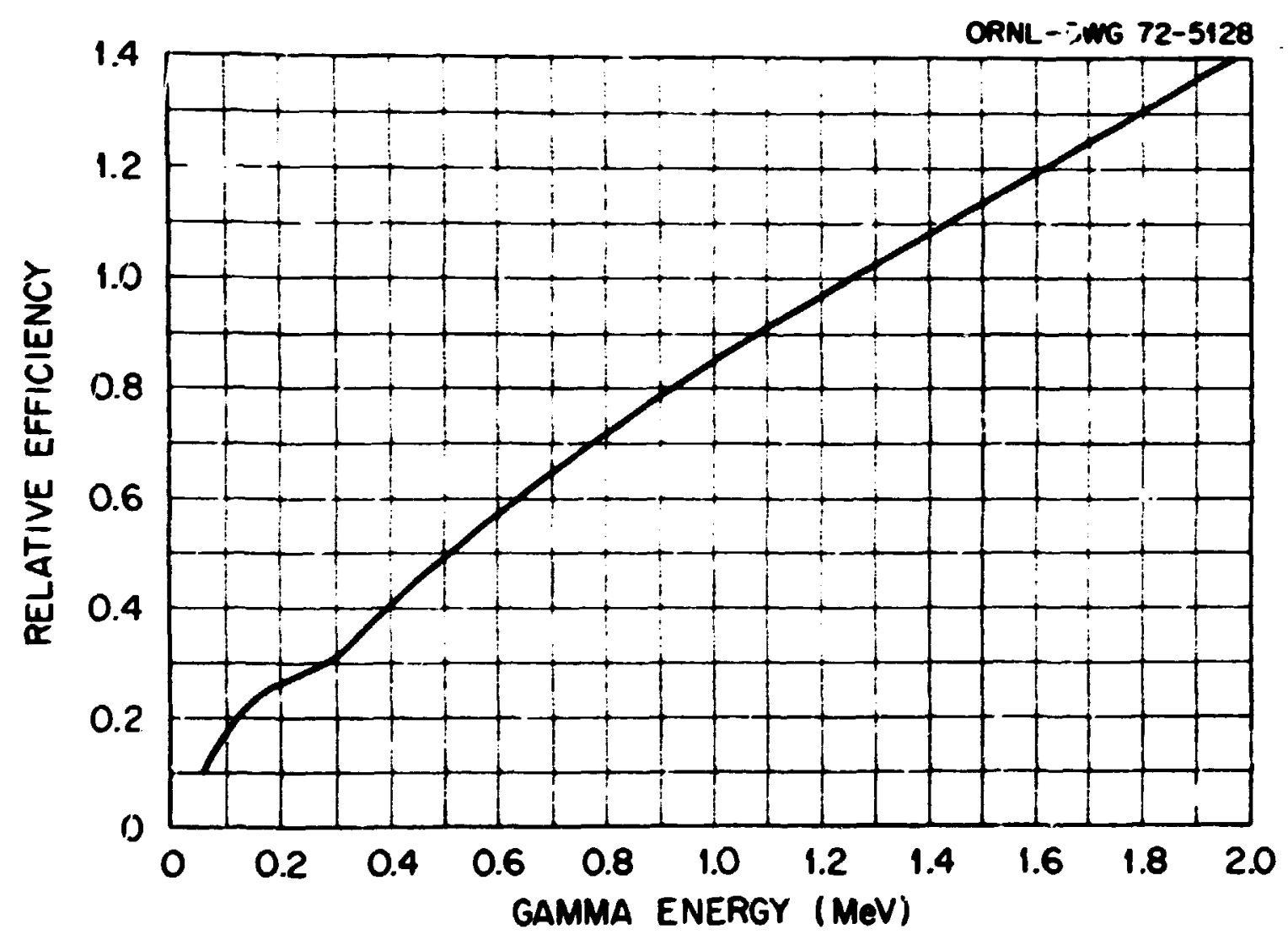

Response of Gommo Ionizotion Chamber.

Pig. 1. Reoponse of Gama Ionization Chamber. 


\section{Quality Control}

Quality of measurements is indicated by precision and accuracy (bias).15 Precisicn is usually characterized by random variation, 1.e., a "plus-orminus" value, and can be evaluated by familiar techniquez; $2,14,15,55,56$ but accuracy implias an absolute, 1.e., a genuine "innown," which obviously does not exist. It has been pointed ou 55,57 that there is no method of rigorously evaluating accuracy, since an unknown source of error may be present.

In case one has obtained a SRM or cajibration from a reputable supplier, say NBS, the stated precision san be combined in quadrature with the user's own precisicn, and the supplier's estimate of bias then added. 55 Uncertainties in half-1ife $e^{58}$ or decay 8 cheme can normally be incorporated in the user's precision, provided they have been statistically evaluated. 2,4 : Unwitting use of an incorrect value, presence of an unknown impurity, or improper chamicai handing ${ }^{i 1,59}$ could of course cause an unsuspected blas. If a standard is not available, a statistical model is difficult to apply. Response curves for instruments could be fitted and errors estimated, but such a procedure would be tedious and uncertain.

It was early recognized at ORNL that errors of activity measurements and ordinary analytical techniques would be small compared to inaccuracies in disintegration-rate determinations, and compared to the warranted 60 radiolsotope-concentration uncertainties of \pm 3 to $\pm 30 z$ - typically $\pm 10 z$. Tterefore, systematic studies were not made, but enough information was collected to show that routine precision ${ }^{25}$ was about 2 to $5 \%$, depending oil the characteristics of particilar nuclides; selected examples are given in Table 2.

It was decided that raking aliquots by weight was not justified, 1.e., the quick and simple volumetric techniques were adequate. Separate portions of samples are taken by two analysts, and limits were prescribed 26 for their agreement. Whenever feasible, measurements are made by instruments of different t;pes, and all calculations ars verified by supervisors. The data of Table 1 generally demonstrate good agreement. with measurements by standardizing laboratories, and some details on individual nuclides are given in a later section.

\section{Personnel}

Responsibility for radiolsotope analysis at ORNL is sharied by a research group and a service group. Some development of methods, decay-scheme research, and special problems are done by the former; the routine work, actual calibrations of equipment, measurements of most standards, and formalization of methods (as in the ORNL Masten Analytical Manual) are done by the latter. In addition, specialists are avidlable in other divisions for consultation and special services. Analytical work is supervised by expericnced people who have degroes in chemistry but gonerally little formei training in radiochemfery. However, all have participated in the author's survey course mentioned in an earlier 
section. Host of che techniclans (nonprofessicial) have anay years of experience in relevant worl:. All personnel now do other work, such as activation analysis, and all equipment is us sd for multiple purposes.

Table 2. Precision Values for Selected Routine Aseays

\begin{tabular}{|c|c|c|}
\hline Nuclide & Instrument ${ }^{b}$ & $\begin{array}{c}\text { Precielon (Z) } \\
(95 \pi \text { C.L.) }\end{array}$ \\
\hline Bydrogen-3 & $\mathbf{i}$ & 5 \\
\hline Carbon-14 & $\mathbf{L}$ & 5 \\
\hline Sodium-24 & $I, S$ & 2 \\
\hline Phosphorue-32 & $\ddot{z}$ & 2 \\
\hline Chlorine-36 & $\mathbf{L}$ & 3 \\
\hline Potessiun-42 & $I, S$ & 3 \\
\hline Calcium-47 & GS & 2 \\
\hline Chrontium -51 & $I, S$ & 5 \\
\hline Iron-5j & $\mathbf{x}$ & 10 \\
\hline Iron-59 & $I, S$ & 2 \\
\hline Nicke1-63 & $\mathbf{L}$ & 10 \\
\hline Arsenic-77 & $\mathbf{P}$ & 5 \\
\hline Krypton-85 & GS & 3 \\
\hline Rutheniu-103 & GS & 5 \\
\hline Rutheniur-106 & $\mathbf{P}$ & 3 \\
\hline Cadntiva-109 & GS & 5 \\
\hline Cerium-144 & $\mathbf{P}$ & 4 \\
\hline Prowethium-147 & $\mathbf{L}$ & 3 \\
\hline
\end{tabular}

Q. S. Lyon, S. A. Reynolds, and R. I. Hyatt, Mucleonics 24(8), 116 (1966).

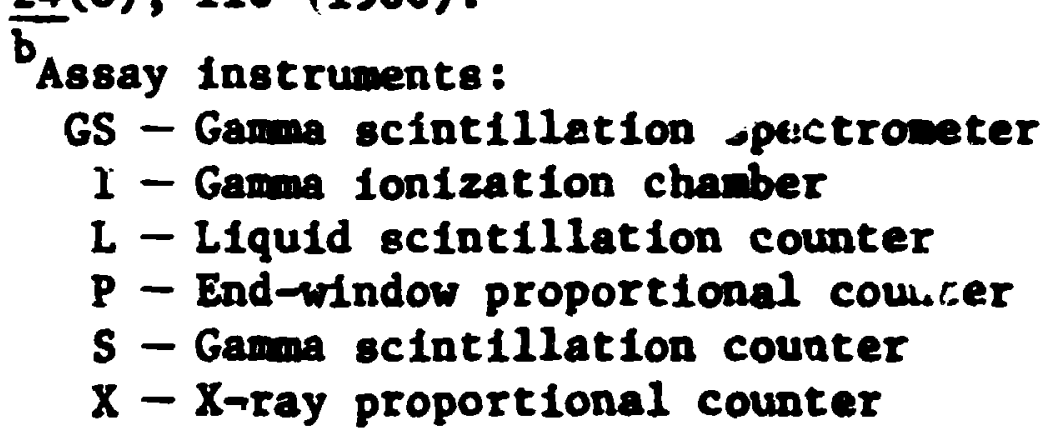




\section{ASSAY OF SELECTED RADIOMUCLIDES}

\section{Caibon-14}

Carbon-14, the origtal radiolsotope pruduct, was understandably of particular concera. The flrst standarde, in 1946, were obtelned from $L$. D.

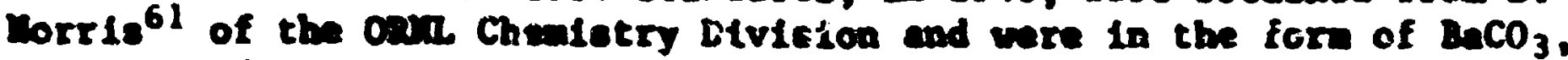
as the producte mre and are. Nesay was done by packing portlons of comple and stendard in wells in met plates and counting by means of an ead-uitidow couster, Interposing an absorber as necnesary to lintt counting iates.

Soon aftar on MS SMY becane ave12able in 1950, the aseay wethod was chenged so vae lnvolving $\mathrm{CO}_{2}$ evolution and masuranent in a beta ionisation chanber.62,63 The wis sia wes compared wth the Hortis acertal, and they were foumd to agree withis 1\%. In 1959, the fresent enthodit of 11quid sclatillation counting was adopted. InS Sw's we purchased as needed, particular'ly as now types - bencois acid in toluene, then bexadecane - were

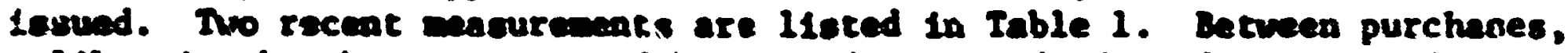
callbiation has been walatalaed by soscodary standards made from products. Diliuctons of eaple and standard are ande eeperetely tecause use of the "standard addit1on" athod (adding a portion of hexadacane standard to the eaple afxture, then recounting) gave anomalous resilts, as reported by Yophise1 65 and (privately) by othere.

A Eassure oi the validity of the local ectivity masureasate is given by occastonal calculatioas ${ }^{2}$ of the balf-ilfe fren spacific activity, consis:watly near the accepted "Cabbridge average" of $5730 \pm 40$ years. A recent value 45,66 was 5736 - 56 years.

\section{chlorine-35}

Cinlorine-36 use originally secayed by maporatiog a neutrallzed saple, followed by routine bets counzing $24,67,46$ by wane of an end-uindow cointer. No external standards were uned unt1l the nuclide becane avallable from IBS in 1962, but an early deteratantion 67 by the author of the beta half-11fe ylelded $0.26 \pm 0.04$ megayear agalast the presently accepted ${ }^{4}$ 0.307 eseayear, ladicating probable eccuracy of assay within 132 or better. Later, liquid scintillation counting was adopted; the date in Table 1 inte ebtained by th1s method.68 Adjuntant was ade after the 1969 masurement, which must have been blased by accidental partial evaporation of a secondary standard.

\section{?ron-55}

ieing callbrations based on coincidence-counted sources of ${ }^{51} \mathrm{Cr}$, ${ }^{54} \mathrm{Mn}$, and $65 \mathrm{zn}$, the early measurements of ${ }^{55}$ Fe were ade by means of a $G-x$. tribe with krypton-ethanol f1lling. 69 Possible uncertainty in the measurenent led to organization of an incercomparison 34 by ORML in 1952, which shoved adequate agraesent. Subsequently, a proportional counter apect-ometer ${ }^{34}, 63$ was used. An ${ }^{55}$ Pe source was maintained for normal1zing 
spectrometer performance. Agreement to $1.6 \%$ was observed with an NBS SRY made avallable In 1961, and local measurement lay between NBS and IARA in 1969 (Table 1).

\section{Iron-59}

Straightforward coincidence counting was used to calibrate GIC's and scintillation counters fcr routine measurcments ${ }^{70}$ of ${ }^{59} \mathrm{Fe}$. Agreezent with NDS (and Huclear-Chicago Corporation) was demonstratea ${ }^{38}$ in 19591960 and in 1370 (Table 1).

\section{Nickel-63}

Micke1-63 has a maximsa beta energy of $0.066 \mathrm{MeV}$ and is difficult to measure. For two decades, stancardization ${ }^{69}$ was based or evaluations ${ }^{71}$ of effictency and self-absorption in a $2 \pi$ proportional counter. In 1960 . liquid scint:1llation counting was adopted for routine weasurement, 72 though the besis of calibration remained the same. Teble 1 shous initial ansay of a SRY in adequate agreervenc, but when ${ }^{63} \mathrm{Hi}$ becase avalleble frow ins, 73 the local measurement was, disappointingly, 172 hig!var than MBS. The calibration was, of course, adjusted to the NBS value. The early ${ }^{71}$ and present ${ }^{73}$ values of the half-1ife, 85 and 100 years, respectively, are in accord with the activity measurements.

\section{krypton-85}

Little atiention $2 a s$ been given ridicessay of ${ }^{85} \mathrm{Kr}$ products, because they are normally dispensed on a voluwetric basis after mass analysis. However, wen MBS 18sued zarian standards of the nuclide in 1970, one was obtained and axsayed by gama spectrometry, with a result $1.7 \%$ higher then NBS. The ampul was retained as a cefereace source for spectrometer or GIC measuremente.

\section{lodine-131}

Because of 1 ts wido use in the blomedicel field, 131 i was the first radiolootope product for which MBS legan a standards program. Some difficulcies were encountered in that the first NBS assays were rade against RaDE (210 $\mathrm{Pb}-$ Bi). Hound lazer ${ }^{21}$ to have a "forward scattering" correction of $7 \%$. ORNL assays by coincidence counting : vere correspondingly higher. 1,21 Subsequentiy, HBS assays were limproved by using $4 \pi$ counting, and disagreement became incignificant 1,2 by 1951. Game fonization thambers and scintillation counters were callbrated for routine mesurements. ${ }^{74}$

\section{Fromethium-147}

Promethium-147 calibrations were wade by $4 \pi$ counting, and routine measurewats were ade on end-alndow detectors until 1954 , when $2 \pi$ proportional counters were dopted. liecause of user difficulties, an intercomparison?5 
was arranged by OBML in 1956 . The Opd masurement was 4.52 above the mean of $81 x$ careful deterninations, which had a standard deviation of $5 \%$. Liquid scintillation counting ${ }^{76}$ we begun in 1959 , with raference wiutions callbrated by $4:$ counting.

No external etandards were obtained, but approximate confiriation of radiaissays was afforded by use of weighed samples of inown chenicel analysis. In 1966, a discrepancy was observed, and an MBS SRM was obtained. Local measurements were found to be $10 \%$, presumably because of evaporation of a referefice solution. The data of Table 1 refer to measurames after making the calfbration traceatice to MBS. The "Intercomparisong" vere against sasies preparec and welghed at Iscific Northwest Laboratories.

\section{SUGGESTIONS FOR RADIONUCLIDE MEASUREAENTS}

This section contains recomendations for those who wake radionuclide measurements and way be producers or users of standards and caltbrations. or both. Obviously the suggestions are not directed to opecialists sino are prepared to do a large variety of direr calibrations. Such capability is not practical for personnel of $a$ : laboratories, who typically deal with fewer than ten nuclides.22 There - no single "best" approach to measurement capability and quality control. Circumstances such as level of funding, number and qualifications of personnel, and interactions with other parts of the or genfation nay be deternining factors. There have been no regulations governing radioassays, despite applications to radiopharmaceuticals used in humans, but imposed quality controls way cose soon. There have been propasals for certificaiton of laboratories and/or personnel (e.e. : by MBS) and issuance of formal piocedures for analysis.

Nuclear data is a perennial problew, often accounting for discrepancles in assays. The Nuclear Data journals contain the best compllat lons 40,41 and should be consulted first, but they neressarily lag behind current 1iterature by as much as seveca? years. If needed information 18 not found, the nuclear-medicine supplements 77 should be examined. Data in tive Table of Isotopes ${ }^{39}$ ay be useful, but one must re rember that none is newer than early 1966. Of course the recent literature contains much information, but it nust be used cautiously besause it is unevaluated, Correlations with earlier findings, and sometimes with theory, are desirable, and thare must be compeling evidence for adopting a value which is very different from others. A conventent sourst for locating such papers, listed under the individual nuclide heading, is Nuclear science Abstracts.

\section{Requirements for Siandards}

The best fcrm of SRM is a sciut on of the nuclide for which calibration is desired. This type is jetter than a mounted source, "point," disk, etc., because the user can prepare it in a form identical to the material to be measured, ard possibj's systematic errors in the user's technique may be compensated. Volumetric techniques are sufficiently accurate for 
not calibrations. If publishand efficiency curves mat be used a fes polnts should be checked by mene of single sint's or mixtures. 78 por bete efficiencies, a bettar plot is obtalned againet sverage rather than mximin carcy. $79^{\circ}$ If a substicute or "bock" stentard is requifed (such as ${ }^{57} \mathrm{Co}$ for 9 nic), It abould be compared with a source of the pure auclide under valid conditions (e.8., use of a spectrometer with enll volames of mterials) and that the pure auxifde can be used to callbrate a working instrument.

For techaical and stacutory ressoas, It is destrable to obtain Sex's and calltrations fron bs. A list of these is atren in Table 3. In addition, WB is pernitesd to callbrste other cuclides at cost, but shat eervice is lintted. If a particular service is unavallable or could be too auch delayed, ancthar supplier ay be uos, ors should require certification

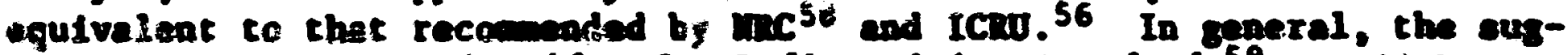

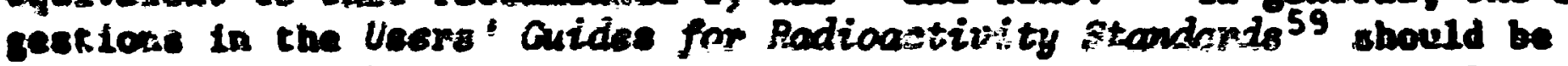

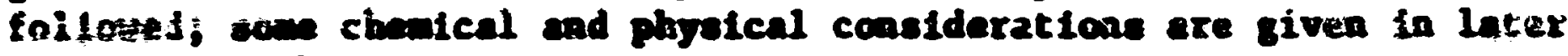
sect loas of this report.

\section{Personat}

It is unrealistic to be dogatic about cyees and qualifications of perconnel in a radicaseay group. An organisation wuet decide shat expertise and services the group wat provide for itcelf, and what can be obtained in otber groups, or even outside organizations (e.8., through eervice contracts with instruant compaies), as well as funding and avatlability of the diestred people.

Minimer gualiftcations aght be as specified in as IAEA handbook 80 for a radiatian-protection group, consisting of a director (supervisor), a phystcist, technicisns as meeded, and a secretary. The handbook indicates that the supirvfscr stould have science or engineering degree, five years of directly releyant experience, and be fantliar with statistical quality control. The p'ysicist spould have sintlar acadente training and two years experfence, while the technicians should have experience in laboratory work and it is "desiratle" that it be in Laz subject field. ANSI'1 ilated sinflar requirenents for power plant personnel. Realistically, the supervisor, at least, should have traipjng someshat like that given radiopharmaclsts ${ }^{B 2}$ (obviously with deletion of wdical items), covering bssic nuclear physics, radiochenistry, instruments and standard. health physics, etc. This should be supplemented by specialized courses or seminars, auch as those taught by RBS and CRAd. Obviously one wust keep up to date by reading the literature.

It has been suggested informily on at least two occastons that radiosseay personnel be cert: 1 led or licensed as are reactor ${ }^{81}$ and fuel-plant ${ }^{83}$ operators. Whether or not this is unjertaken by a concerned agency (such as FDA for radiopharaaceuticals), laboratory management should ake surt such work is being done competently and consclentiously, becalive of the grave responsibilities entalled. 
Table 3. Standards and Routine Callbration Servicee of ms $^{a, b}$

\begin{tabular}{|c|c|c|c|}
\hline Mucilde & Service ${ }^{c}$ & Buclide & Service ${ }^{c}$ \\
\hline Dydrogen-3 & $\mathbf{s}$ & Mlobiu-94 & $\mathbf{P}$ \\
\hline Carboa-14 & $\mathbf{s}$ & Miobiven-95 & c \\
\hline Sodium-22 & $S, P, C$ & Cadaturas 109 & $\mathbf{P}$ \\
\hline Sodium-24 & c & In-113-Iadiun & c \\
\hline Alvainum -26 & $\mathbf{s}$ & Iodine-125 & C \\
\hline Phosphorus-32 & C & Iod Ine-131 & C \\
\hline Sulfur-35 & C & Cesiu-137-Bariun & $P, C$ \\
\hline Calorine-36 & $S, C$ & Cer1um-139 & C \\
\hline Potarstum-42 & C & Cerive-141 & $\mathbf{c}$ \\
\hline Calcium-45 & c & Cerfun-14h-Praseodyniun & $\mathbf{s}$ \\
\hline Scand $1 u=46$ & c & Prowethive-147 & $S, C$ \\
\hline Chrontum-51 & c & Tantalum-182 & C \\
\hline Manganese-54 & c & Cold-198 & C \\
\hline Irot -55 & $\mathbf{s}$ & Mercury-197 & $c$ \\
\hline Iroa-59 & C & Mercury-203 & c \\
\hline Cobalt -57 & s,c & Thall 1u= -204 & C \\
\hline Cobalt -60 & $\mathbf{P}, \mathrm{C}$ & Polontum-210 & $P, C$ \\
\hline stckel-63 & $\mathbf{s}$ & Radiue -226 & s,c \\
\hline 2 inc-65 & C & Thor 1um-228 & $\mathbf{P}$ \\
\hline Krypton-85 & Gas, P & Urantum -235 & $\mathbf{x}$ \\
\hline Stront 1um-85 & $\mathbf{C}$ & Plutonium-238 & $\mathbf{P}$ \\
\hline Strontium-89 & C & Plutoni um-239 & $x$ \\
\hline Strcatiun-90-Yctrium & C & Anericium-241 & $\mathbf{P}$ \\
\hline Yttrium-88 & $\mathrm{I}, \mathrm{C}$ & & \\
\hline
\end{tabular}

astandard Reference Materials, MBS Spec. Publ. 260, Govt. Printing office, Washington, D.C. (semiannually).

${ }^{b}$ Calibration and Test Serviose of the llational Bureau of Standands, NBS Spec. Publ. 250, Govt. Printing of fice, Washington, b.C. (1970) (revised pages and new editions as needed).

${ }^{c}$ - callbration rout inely available

$P=$ point or plate source

$S=$ solution standard

$X=$ sol1t 


\section{Er,uipunt}

Much bas been published $15.26,41$ on op paratus for radloassay work. Ordinary laboratory equipmant isually suffices. Radiation-protection provisions such as shielding and glove boxes wy be needed, but less so than in facilities for proceseing or shipping mfor quantities of radiolsotopes. The variety of masurcment devices depends on the wuber and type of nuclides to be aseayed. For hard-bete and gana nuclides, an snd-rindow counter,

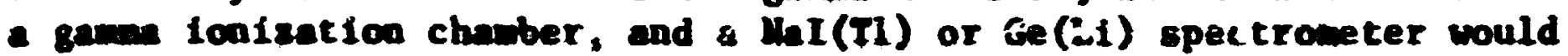
suffice. (Some duplication for "standty" capability ay be needed.) For soft-beta nuclides, a liquid scintillation counter is indicated. The same device might be used for aipha, or a 2 in proportional counter aight be chosen. A 81 (Li) or proportional-counter spectrometer would be useful for low-energy $x$ rays, althoigh liquid scintillation has been used.84

Redundance if ephasized, especially in masuring the total activity dispensed in a secoadary standard or a shipment. This can be done, in many cases, by tice of a 4i lonization chaber or an externa: chamber, reading in dose units, and estinating content by use of the specific gana--ay constant. 14,85

\section{Some Physical Sources of Error}

Phyalcal conalderations in calibration have been generally discussed.1!,59 Aseumptions of the urong decay scheme or half-life clearly can cause error. "Drift" can be compensated by reading an appropriate normalizing source. If readinge are made on a weter, typical "ix-of-full-scale" accuracy is not sufficient, forcing use of an expanded scale or "nulling."52 Differeaces In activities of standard and unlnown can lead to errors if the instrument Is nonlinear and appropriate corrections are not made. Autonatic livetimers sometines alfunction and way not properly correct the date in any case. 86 The appreciable dead t1mes of "fast" counters, typically 8 usec 87 (1.e., about 1.32 correns:on at 100,000 counts/min), may be erroneously ignored. Various artifacts, such as scattering, gpstial location of posttron annihilation, and coincidence and randon ${ }^{2}$ suming, have been studied. ${ }^{8}$ Suning may have both positive and negative effects by creating a spurious peak at $\quad$ igh energy at the expense of one or more primary peaks. Conditions of use such as "geometry" (spatial relationship of source and detector) and absorption may not be made identical for standard and unknown.

The effect of a radionuclidic Impurity may range from nil to very large, depending on the radiations of product and impurity and on the measurement method. Clearly, the effect may vary with time because of the different half-lives involved.

\section{Chemical Considerations}

Usual good laboratory practices must be followed, and specsal attention is required for 1tems such as "contamination" and sorption, which are die in part to the extremely small masses of radioelements.89 Manuals ${ }^{14,59}$ 
contain auggestions on chenical problems, and recent publications ${ }^{90-92}$ give useful data. Volatility is encountered anong noble gases, halogens, and som other elements such as meresy. Deposition fron solution is a problem unless precautions are teken. Obviously troublesone are niobium, sirconlun, rare earths, and like elenents; but "soluble" sodium, rubidium, and cesiu can deporit if exchange sites are afforded, e.g., glass exposed to a neutral solution. Sorption can often be mininized by adding carrier, complexing agent, or acid (for cat1ons). "Wash-out" micropipets should be used to lessan deposition, as well as because of their accurasy.

Liquid scintillation counting is subject to interferences ${ }^{93}$ such as quenchIng, chemllumescesce, and sorption, which are poorly understood and may not be anticipated in a particular case. It may be necessary to confirm measurements by a different method, to try various "cocktalls," or to add car: 1 er.

If radiochenical analysis is required (e.g., chentcal separation of a ninor inpurity), approaches and procedures have been recomended. 26,94,95

\section{Quality Control}

Standard quelity-control methods ${ }^{96}$ are applicable to radiolsotope work; these include control charts, knowns, blind duplicates, and othe: devices. Intrinsic Eessurement precision, typified by counting stailstics, must be takes into consideration 97,98 and is an essential factor in evaluating instrument performance or "constancy." 80 0ther factors are usually dominant in overall accuracy; 56,57 examples are such additional sources of randon error as pipetting: indeterminate ones involved with efficiency plots, and sysiematic errors in decay schemes or calibrations of standards. It is thue impossible to rake rigorous statements about accuracy; tut an estimate is made hy combining precision terms in quadrature and adding the estimated systematic error. 56

It is a mistaike to ass1gn all measurements a "blanket" warranty, e.g., "5\%," since actual uncertainties vary widely. 80 objective intercomparisons have revealed an almost universal tendency to underestimate errors, often by forget ing systematic sources.

Instruments must be calibrated when installed, when major repasts are made, or yearly in any case, 80 and performance must be tected with a reference source daily, $c^{-} t$ every period of use. Redundance is desirable in measuretent (by different types of instruments if feasible) and in calculation. A final check, e.g., with an ionization chamber or remote spectrometer, serves to detect mismeasurement or mistaken identity.

Participation in intercomparisons is urged, whether tro- ir multi-laboratory. Some organizations have set up very meaningful. "round robins," including the IJRC standards subcommittee, 13 the College of American Pathologists 93 (who arranged three in 1972), and the Society of Nuclear Medicine. 100 Traceaility to NBS is an essential feature of these efforts and is now achiev 2 d through individual arrangements, but it is expected to 
be handled through the Measurement Assurance Program in the future. A group to study standard methodology for measurements was formed by the Atomic Industrial Forum and was recently transferred to ANSI 1344.

One could continue with discussion of formalities of quality control, but the essential featcre is integrity. No program can be successful without conscientious, intelligent work by concerned individuals.

\section{ACKNOWLEDGMENTS}

The author acknowledges with appreciation the essential contributions of several colleagues. W. S. Lyon did most of the direct calibrations until 1961 and has since supervised the responsible research group. J. S. Eldridge has made most of such calibrations recently. E. I. Wyatt has supervised the control laboratory throughout most of the period, and $W . T$. Mullins and H. A. Parker have teen specifically charged with radioisotope work in recent years. Support and encouragement have been given by $A$. F. Rupp and J. H. Gillette of the Isotopes Development Center, M. T. Relley and J. C. White, former and pisistat directors of Analytical Chemistry, and personnel of the former AEC Division of Isotopes Development, who requested the preparation of this report. Some of those named have reviewed this material, but the author retains reponsibility for any errors of fact or opinion. He has learned much from associates in several national organizations, particularly W. B. Mann and the late S. B. Garfinkel of NBS. 


\section{REFERENCES}

1. S. A. Reynolds, Rec. Chem. Prog. 16, 99 (1955).

2. S. A. Rejmolds, Isotop. Radiat. Feckncl. 4, 46 (1966).

3. "Cooperat \&ve Isotopes Progrum," in anrual progress reports oz Lho 'alytical Chemistry Division, e.g., ORNL-4838, pp. 31-3 (1973).

4. Isotopes development program reports, e.g., AEC Report TID-4067, pr. $40-7$ (1972).

5. A. F. Rupp, in Nuclear Stondards for Shemistry and Technology, NBS Spec. Pul1. 310 (1968).

6. S. A. Reynolds, Health Phys. 8, 391 (1962;.

7. J. C. Posev, I6otop. Radiat. Technol. 1, 92 (1963).

8. S. R. Gunn, Nuel. Instis. Meihods 29, 1 (1964) and 85, 285 (1970).

9. Sperification of High Actinity Samma-Ray Sources, ICRU Report 18, Int. Com. Rariat. Units and Hersurements, Washington, D.C. (1970).

i0. Division of Applied Technology, Laotopes Development Programs, Besearch and Deve iopment 1971, TID-406? (February 1972), pp. 134-5.

il. B. J. Wilson, ed., The Radiochemical Manul, 2nd ed., Radiochemical Cencre, Amersiam, England (1966).

12. M. R. Weiler and W. Y. Matsumoto, "Radionuclide Standards at the Pacific Northwest Laboratory," Gatlinburg Analytical Conference, Sept. 30, 1969.

13. B. Kahn, in liuclear' Stardards for Chemistry and Tectrolcgy, HBS Spec. Publ. 310 (1968).

14. A Moriual cf Radioactivity Procedures, Report 28, National Coincil. on Radiation Protection and Measurements (NCRP), Washiogto., D.C. (1961); NB's tandbook 80 (revision in progress).

15. Anrual Book of ASIM Staniards, Part jo.

16. Measurements and Standands of Radioactivity, Nuclear Science Ser. Report 24, Naticnal Academy of Science-liat:ioual Research Counc11 Pub1. 573, Washington, D.C. (1958).

17. Metrology of Radionuciids:8, International Atomic Energy Agency, Vienra (1960).

18. Stundardization of Radionucli ies, International Atomic Enerzy Agency, Vienna (1967). 
19. W. S. Lyon, Anal. Chem. 30(2), 31A (1964).

20. S. A. Reynolds, A Survey of Needs for Radiuactivity Standards, ORNLTM-3239, Oak Fidge National Laboratory (1970).

21. G. G. Manov, Status Report on Stondardization of Rudionuclides in the United States, Preliminary Report 13, National Research Council; AEC Repo:t NP-4664 (1953); also Ann. Rev. Nucl. Sci. 4, 51 (1954).

22. National Uses and Needs for Standard Radioactive Materials, National Academy of Science, Nashinzton, D.C. (1970).

23. W. F. Lisby, Anal. Chem. 29, 1566 (1957).

24. E. Segre, ed., Experimental Huclear Pinysics, V. III, pp. 10-13, wiley, Hew York (1959).

25. W. S. Lyon, S. A. Reynolds, and E. I. Wyatt, liucleonics 24(8), 116 (1966).

26. ORNL Master Analytical Manual (especially Secs. 2 and 9), AEC Report TID-7015 and supplements, Oak Ridge llational Lai ratory (1957-67).

27. F. E. McKinney, S. A. Reynolds, and P. S. Baker, Isotope User's Guide, ORNL-IIC-19, Oak Ridge National iaboratory (J.969).

28. W. B. Mann and 1. H. Seliger, Preparation, Maintenance, and Application of Standards of Radioactivity, Circ. 594, NBS, Washington, D.C.; also Int. J. App 2. Radiat. Isotopes 1, 3, 215 (1956).

29. W. B. Mann and S. B. Garfinkel, Radioxctivity and Its Measurement, Van Hostrand, Princeton (1966).

30. W. B. Mann and S. B. Garfinkel, eds., Radioactivity Calibration Stcondards, Spec. Publ. 331, NBS, Washiagton, D.C, (1970).

31. Radioisotope Production anả Quality Control, STI/DOC/1n/128, International Atomic Energy Agency, Vienna (1971).

32. W. S. Lyon and S. A. Reynolds, Nucleonic8 14(12), 44 (1956).

33. P. J. Campion, in Measurements and Standards of Radioactivity Nuclear Science Ser. Report 24, Jational Academy Science-National Research Council Publ. 573, Washington, D.C. (1958); alsn Int. J. Appl. Radiat. Isotopes 4, 232 (1959).

34. W. S. Lyon and S. A. Reynolds, Int. J. Appl. Fadiat. Isotopes 2, 80 (1957).

35. G. Goldstein, Nucleonics 23(3;, 67 (1965). 
36. Stcondard Reference Haterials, NBS Spec. Publ. 260, Government Printing of fice, Washington, D.C. (seaiannu-liy).

37. Calibration and rest Services of the National Bureau of Standards, N3S Spec. Publ. 250, Government Printing Office, Washington, D.C. (1970) (revised prges and new editions as needed).

38. W. S. Lyon, H. A. Parker, and S. A. Reynolds, in Analytical Chemistry Division Annual Progress Report, December 31, 1961, ORNL-3243, Oak Ridge National Laboratory, PP. 60-2.

39. C. Y. Lederer, J. H. Eollander, and I. Perlman, Tabily of Isotopes, 6th ed., Wiley, New York (1967).

40. Journal thuclear Data, Parts A and B, published by Acadenic Press.

41. M. J. Martin and P. H. Blichert-Toft, Mucl. Data Ấ, 1 (1970).

42. Nuciear Data Compilations, Mational Acadeny of Science, Maghington D.C. (1971).

43. G. Goldsteln and S. A. Regnolds, Bucl. Data Al, 435 (1966).

44. S. A. Reynolds, in Bandbook of Analytical Chemistry, L. Heites, ed., Pp. 7-14 to 7-39, McGraw-Hi11, Hew York (1963).

45. Latest publication: J. F. Bmery, S. A. Reynoids, E. I. Hyat, and C. I. Gleason, thucl. Sci. Eng. 48, 319 (1972).

46. W. J. Frice, Mulear Radiation Detection, 2nd ed., MeGraw-Hill, New York (1964).

47. R. T. Overman and H. M. Clark, Radivisotope Techriques, McGrawH111, New York (1960).

48. Anmual Book of ASTM Standards, Part 30, Method E 18i; ORNL Master Analytical Manual, AEC Report TID-7015, Oak Ridge Hational Laboratory, (1957-67), Nethod 90733001.

49. F. Adans and R. Dans, Applied Ganna-Ray Spectrometry, 2nd ed., Perganon Press, New York (1970).

50. R. L. Heath, Scintillation Spectronetry Orimma-Ruy Spectmon Catalogue, IDO-16880, Phillips Petroleu Company (1964).

51. J. W. Jones and R. T. Overman, The Use and Ca?ibrition of a 100\% Geometry Ion Chamber, AECD-2367, Oak Ridge National Laboratory (1948).

52. ORNL Master Snalytical Manual, ARC Report TID-7015, Oak Ridge National Laboratory, (1957-67), Method 900360. 
53. ORNL Maste: Analytical Manual, AEC Report TIL-7015, Oak Ridge National Labo:atory, (1957-67), Method 90733002.

54. J. W. G. Dale, W. E. Perry, and R. F. Pulfer, Int. J. Appl. Radiat. Isotopes 10, 65 (1961).

55. J. Mandel, The Statistical Analysis of Experimentai Data, Intersclence, New York (1964).

56. Certification of Standandized Radioactive Sources, ICRO Report 12, Int. Con. Radiat. Units and Measurements, Washington, D.C. (1968).

57. L. A. Currie, Mucl. Instr. Methods 100, 387 (1972).

58. S. B. Garfinkel, A. P. Baerg, and P. E. Zigman, Certificates of Radioactivity Stondards, Mational Academy of Science, Washington, D.C. (1966).

59. B. Kahn, G. R. Choppln, and J. G. V. Taylor, Users' Guides for Radioactivity Stcondards, National Acadeny of Science, Washington, D.C. (1967) (revision in progress).

60. Research Materials - Separated Isotopes, Radioisotopes, Special Preparations, Oak Ridge Mational Laboratcry (1973).

61. L. D. Norris and M. G. Inghran, Phys. Rev. 73, 350 (1948).

62. ORIL Master Analytical Marnal, ABC Report TID-7015, Oak Ridge National Laboratory (1957-67), Method 90733172.

63. C. J. Borkowbk1, Anal. Chem. 21, 348 (1949).

64. ORNL Master Analytical Manual, AEC Report TID-7015, Oak RIdge National Laboratory (1957-5?), Method 90733173.

65. A. A. Koghiss1 and M, H. Carter, Anal. Chem. 40, 812 (1968).

66. S. A. Reynolds, in Anaïytical Chemistry Division Annual Progress Report, Sept. 30, 1988, ORkL-4343, Oak Ridge Hatiolial Laboratory, p. 77.

67. H. W. Wright, E. I. Wyatt, S. A. Reynolds, W. S. Lyon, and T. H. Handley, Nuci. Sci. Fing. 2, 427 (1957).

68. ORNL Master Anäytical Manual, AEC Report TID-7015, Oak Ridge Nacional Laboratory (1957-67), Method g 0733201.

69. W. S. Lyon, S. A. Reynolis, and T. H. Handley, In Analytical Chemistry ivivision Quarterly Progress fieport, June 30, 1950, ORNL-798, Oak Ridge National isaboratory. 
70. ORNL Master Analytical Manual, ABC Report TID-7015, Nak RIdge Mational Laboratory (1957-67), Hethod 90733411.

71. A. R. Bros1, C. J. Borkowsk1, E. E. Conn, and J. C. Griess, Jr., Phys. Rev. 81, 391 (1951).

72. ORNL Master Analytical Manual, ARC Report TID-7015, Oak RAdge National Laboratory (1957-67), Method 90733541.

73. I. L. Barnes, S. B. Garfinkel, and H. B. Mann, Int. J. Appl. Radiat. Irotopes 22, 777 (1971).

74. ORML Naster Analytical Narsal, AEC Repori IID-7015, Oak Ridge liationsi Laboratory (1957-67), Methods 90733391,90733392 , and 90733393.

75. S. A. Reynolds, In Measurenents and Stcandards of Radicactivity, Nuclear Science Ser. Report 24, Llational Acadeay of Science-hational Research Counc1l Publ. 573, Washington, D.C. (1958), PP. 106-108.

75. ORNL Master Analytical Marual, AEC Report IID-7015, Oak R1dge National Iaboratory (1957-67), Method 90733661.

77. I. T. Dillman, J. Nucl. Med. sup. 2 (1969) and 4 (1970) (revision in progress).

78. SRM'B 4252 and 4253, bulletin fron MBS (December 1972).

79. A. Raraswami, S. P. Dange, S. Prakash, and M. V. Ramaniah, Determination of Absolute Disintegration Rates of Beta-Ganma Emitters, BARC-552, Bhabha Atonic Research Centre, Bombay (1971).

80. Handbook on Calibration of Radiation Protection Monitoring Ine mumints, STI/DOC/10/133, Internetional Atonic Energy Agency, Vienna (1971).

81. Selestion and Training of Muclear Power Plant Personne?, AMSI M18.11971, America: Hational Standerds Instirute, New York.

82. M. Tubis, in Ridiopharmaceuticals from venerator-Produced Radionuclides, STI/PUB/294, FP. 3-9, internationsi Atonic Energy Agency, Vienna (1971).

83. R. E. Brooksbank, D. J. Skovholt, and W. H. Lew1s, Licensing O:' Keprocessing PLant Operators, ORML-TM-2573, Oak Ridge lational Laboratory (1969).

34. D. I. Borrocks, int. J. Afp2. Radiat. Isotopes 22, 258 (i971).

85. D. Nachitgall, Tatle of Sperific Garma Ray Constants, R. Thienig, Munich (1969).

86. W. Filippone and F. J. Munro, Hucl. Sci. Eng. 47, 150 (:972).

87. C. B. Nelson, J. M. Hard1n, and G. I. Coats, Nucl. instr. Methods 97, 309 (1971). 
88. W. S. Lyon, J. S. Eldridge, ana P. Crowther, in Radiochemica? Methods of Analysis, V. II, PP. 33-46, Interuational Atomic Energy Agency, Vtenna (1965).

89. I. M. :urenan, Analytical Chemistry of Iow Concentrations, Isreel Progran for Scientific Translations, Jerusalem (1968).

90, K. Kepak, Chem. Rev. 71, 35? (1971).

91. E. P. Johnson and G. C. I swenthal, Int. J. App I. Radizt. Isotopes 23, 196 (1972).

92. A. G. Tuck and A. Mcllair, Int. J. Appl. Radiat. Isotopes 23, 395 (1972).

93. P. F. Davidson end I. P. Andersson, Anal. Biochem. 47, 253 (1972).

94. J. H. Harley, BASL Procechures Nomul, BASL-300, Health and Safety Laboratory, Hew York (1972).

95. National Research Counc1l Subcomitzee on Radiochenistry, monographs on the rudtochenistry of the elenents, MAS-IIS-3001 et seq., and iadios'ientcal techniques, MS-NS-3101 et seq. (1960--).

96. ASTM Mankal on Quality Control of Materials, aTP 15-C, ASTM. Philadelphia (1951).

97. H. E. Rolde, Quality Control of Radioactivity-Connting systems, PHS Publ. 999-RH-15, Government Print!ng Office, Washignton, D.C. (1965).

98. E. G. Andresen, Kerntechnik 14, 226, 360 (1972).

99. L. M. Kushner, (NBS) Tech. News BulZ. 56, 219 (1972).

100. S. Genna, et al., J. Miel. Med. 13, 285 (1972). 